\title{
INTELLECTUAL-CREATIVE, SOCIO-PSYCHOLOGICAL APPROACHES IN THE MANAGEMENT OF A MULTINATIONAL STAFF TEAM
}

\author{
C Zaira M. Magomedova, Maida G. Mustafaeva, Zarema S. Mustafaeva
}

\author{
Dagestan state pedagogical university. Makhachkala, Russian Federation \\ science-almanac@mail.ru
}

Intellectual-creative and socio-psychological approaches in the management of a multinational staff team are analyzed. The optimal mastery of management of a multinational staff team in the conditions of the Republic of Dagestan is considered within the context of the pedagogy and psychology principles. It has been emphasized the special role of tolerance as a personal value that a team leader must have in practical goals achieving. The professional success of leader's professional activity depends upon the ability to create the process of managerial communication, to establish and develop relations with people. It has been argued that tolerance assumes the manifestation of participants personal qualities in a multinational staff team and forms a willingness to accept others as they are. The author's concepts of the leader management culture, connected with a personal relationships culture development are considered. The importance to use professional ethics by the leader, where the duty negligence, mistakes create difficulties, problems leading to losses, failures in work has been marked. It is proved that the manager must conduct a preliminary orientationstudy of the team. Reliance on "collected primary information" about a multi-ethnic team will help to plan and implement interethnic communication. The structure of professional mastery of managerial activity is revealed, which includes a system of professional (special) knowledge in the field of management theory, as well as a system of knowledge, skills, personal relationships, its spiritual, personal, ethno-national and professionally important qualities. The importance of development of ethno-psychological properties, determining unique character and personality individuality in the manager professional activity is proved. During the implementation of the study, the structure of the professional skills of the leader has been presented, which includes general, general scientific, general cultural, spiritual, ethno-psychological, ethno-pedagogical, artistic and creative aptness.

Key words: optimal, management, international communication, team subject, sufferance, complement activity, pedagogy and psychology of managerial communication, tolerance.

[3.М. Магомедова, М.Г. Мустафаева, 3.С. Мустафаева Интеллектуально-творческий, социопсихологический подходы в управлении многонациональным коллективом]

Анализируются интеллектуально-творческий, социо-психологический подходы в управлении многонациональным коллективом. Рассматривается оптимальное мастерство управления многонациональным коллективом в условиях Республики Дагестан, в контексте законов педагогики и психологии. Подчеркивается особая роль толерантности как личной ценности, которой должен обладать руководитель коллектива в достижении практических целей. От умения выстраивать процесс управленческого общения, устанавливать и развивать взаимоотношения с людьми зависит профессиональная успешность руководителя профессиональной деятельности коллектива. В работе аргументируется положение о том, что толерантность предполагает проявление личностных качеств участников многонационального коллектива и формирует готовность принять других такими, какие они есть. Рассматриваются авторские концепции об управленческой культуре руководителя, связанной с условием развития культуры человеческих взаимоотношений. Отмечается важность использования руководителем профессиональной этики в коллективе, в котором пренебрежение долгом, ошибки, халатность создают трудности, проблемы, ведущие к потерям, сбоям в работе. Доказано, что управленец должен проводить предварительную ориентировку-исследование коллектива. Опора на «собранную первичную информацию» о полиэтническом коллективе, поможет ему правильно спланировать и осуществлять само межнациональное общение. Выявлена структура профессионального мастерства управленческой деятельности, которая включает систему профессиональных (специальных) знаний в области теории управления, а также систему знаний, умений, навыков, отношений личности, ее духовно-личностных, этнонациональных и профессионально важных качеств. Обосновывается важность развития этнопсихологических свойств, определяющих уникальность и неповторимость личности в профрессиональной деятельности управленца. В ходе реализации проведенного исследования представлена структура профессионального мастерства руководителя, в которую входят общая, общена- 
учная, общекультурная, духовная, этнопсихологическая, этнопедагогическая, художественнотворческая одаренность.

Ключевые слова: оптимальный, управление, межнациональное общение, коллективный субъект, терпимость, комплиментарность, педагогика и психология управленческого общения, толерантHOCTь.

Zaira M. Magomedova - senior lecturer. Dagestan state pedagogical university. Makhachkala, Russian Federation.

Maida G. Mustafaeva - PhD of philosophy, professor. Dagestan state pedagogical university. Makhachkala, Russian Federation.

Zarema S. Mustafaeva - candidate of philosophy, associate professor. Dagestan state pedagogical university. Makhachkala, Russian Federation.

Магомедова Заира Магомедовна - старший преподаватель. Дагестанский государственный педагогический университет. Махачкала, Россия.

Мустафраева Маида Ганифраевна - доктор философрских наук, профрессор. Дагестанский государственный педагогический университет. Махачкала, Россия.

Мустафраева Зарема Сиражудиновна - кандидат философских наук, доцент. Дагестанский государственный педагогический университет. Махачкала, Россия.

Optimal managerial interethnic communication in a multinational team is, first of all, the ability of the leader to influence the team and for each of its members separately on the basis of a full possession of the managerial and pedagogical communication technologies. The modern leader should be able to read on the faces of his colleagues "not only the causes of mental movements", but also their state of health, mood, convictions, sympathies, antipathies. The optimal managerial and pedagogical skills of the leader are reflected in the ability to control his/her voice, face, gestures, role, etc. A.S. Makarenko said that the leader as a lecturer should be able to play different roles. There should be no leader who does not know the principles of psychology and pedagogy and who cannot fully play his professional and managerial roles. Of course, he plays these roles not as an actor on stage, purely externally, artificially. According to A.S. Makarenko, under the collectivist, labor relations "should be some belting, which appealed to connect personal and performing roles in the leader". "I became a real master then, "he noted, "when he learned to say" come here "with 15-20 shades, when he learned to give 20 nuances in the formulation of a person, figure, voice". Indeed, the production of voice, facial expression, the ability to "hold the pose", the ability to get up, sit down, it should seem, every "trifle" has a special significance in optimizing the managerial activities of the manager $[1 ; 2 ; 12]$.

Every word that sounds from the lips of the leader must be nationally and internationally thought out, wise, purposeful, original-attractive, kind, sensibly demanding, culturally-moral, objective, weighty. The leader should know that these words are addressed to the conscience of the entire multinational team, to each of its members, that is, to a living concrete individual, the "team subject" with whom he as the leader is dealing. Therefore, he should not devalue his words, but, on the contrary, he must achieve a constant increase in their rating, their "prices". As a consequence, it should be said that every word expressed by the leader in a multinational team must give its internationally good results, its results, and not turn into empty talk.

The word of the multinational team leader is primarily an instrument of humanity, of high interethnic culture, of tolerance, of complimentarity and sensitivity. The leader should be cautious so that his word does not hurt, could not burn or leave a scar in the soul of a person of another nationality. The words of the multinational team leader should spare and protect, reflect the truth and reassure, they cannot be false, prejudiced. The leader learns to manage the tolerant and empathetic tone of addressing the team, its members. He 
should address them not in a special (official) or usual tone, but in the tone of an unusual, individualized, attractive conversation. If the leader is tongue-tied, then he, first of all, will lose his managerial positions [2; 16].

The managerial culture of the leader is connected with the condition for the development of human relationships culture. And only that leader has the right for sonorous title, who can disclose a fully-featured personality, harmony of internal and external charisma in professional-pedagogical, managerial communication in a multinational team and with each of its. The leader as a psychologist and lecturer must expertly possess the tools of art creation, interethnic communication, art of educating influence. He always "consults" with promptings of his wise thoughts about national and external and etc. The modern leader of a multinational team (manager) has a special managerial talent, managerial intuition for full, effective and efficient implementation of these rules. In the multinational team he manages, he creates such conditions that would give each ethnolity the opportunity to express itself with the greatest completeness personally and nationally. And for this, the leader needs to have modern psychological and pedagogical technologies of personality formation, i.e., theory of teaching and upbringing, which, in the words of D.A. Komenskii, is a "machine for the education of the individual".

Theorists N.A. Ageeva, D.A. Dzhioeva, O.N. Kamalova note in their research that the optimization and effectiveness problems of managerial, professional psychological and pedagogical communication in the team work cover the whole concept of "teaching, educating multinational communication", interpersonal-interethnic subjectivity, selectivity, emotional and semantic relationships, verbal and external interethnic attraction, vulnerability, sensuality, suggestion, infantilism, artistry, physical and moral-psychological comfort, etc [3, p. 40-41; 6, p. 137].

There is a particularly specific psychological and pedagogical system of professional requirements for modern management by a multinational labor team, not exhausted by theoretical or other knowledge, obtained by them in the process of mastering a higher managerial or other education. The main thing in the renewing special requirements is a system of multinational, universal, comprehensive, sometimes even especially unique, multinational knowledge, skills. It reflects the essence of various types of human activity, in which the manager is included, and manages any person of any nationality. In this connection, it is important to emphasize that administrative interethnic communication as a psychological and pedagogical system requires the manager to ensure that his communication in a multiethnic team is effective.

The preliminary orientation will allow, based on the "selected primary information" about a multi-ethnic team, to plan and implement interethnic communication correctly. And this requires from the leader to search the answers to the questions of innationallyunknown. The questionnaire consists of the following questions on the identification of the general attitude towards the acceptance of another person, as well as the formation of ethnic self-awareness and inter-ethnic relations. Questions can be formulated this way: How should I communicate with people of different nationalities? What should I achieve in the process of communicating with them? What is formal and informal, direct and indirect (virtual) interethnic communication? What are the psychological and personal characteristics of multinational team members? What is effective, complimentary interethnic communication? How do you understand the social roles and the role of the ethnomotivation factor in the process of communication? How do you understand interethnic communication by the method of "trial" and "mistakes"? What is interpersonal-interethnic subjectivity, empathy and tolerance in the process of communication of nationalities? Are there any special methods for resolving the contradictions that arise in the process of interethnic communication, etc.? [11; 15, p. 70$]$. 
At the present time, the problem of management and managerial culture in the process of communication in the system of multinational collectivist attitudes in sociopedagogical and ethnopsychological science is one of the actual and important components, associated with the process of establishing harmonious interpersonal contact and mutual understanding. On the one hand, in order to manage a multinational work team, the leader must himself expertly master the means, methods, word, that is, the entire technology of establishing and maintaining interpersonal contacts for the sake of arbitrary management (ownership) of the process of interethnic communication. On the other hand, the leader should train this particular multinational team, each member of the organization, at least to the minimum of the fundamentals of the science and art of interethnic communication in this team.

The foregoing allows us to conclude that intensive, non-mediocre, lively interethnic communication in the system of managerial and collectivist relations is highly desirable and necessary. Knowledge and skills of pedagogy and psychology of managerial communication are among the professional skills of the manager as an integral part of him. Intensive communication in a multinational labor team is impossible without them. Analysis of the results of our study showed that gradually in Russia we will have to deal with a new type of managerial leader, with the leader of the future. The personality of the future manager is not only an educator, psychologist, who actually should form spirituality in a multiethnic team, but also has a professional and educational impact on the whole team.

The analysis of practice has shown that a spiritual climate in all multinational teams first of all depends upon the talent of the new generation leaders, upon their erudition and heart generosity. These teams will gradually bring up that moral type of ethnolity that will meet the requirements of the future information civilization [13; 15, p. 72]. In other words, if we poorly prepared the future managers of multinational teams as practical lecturers and psychologists, if they do not know how to provide the optimal relationship in these teams, they are not able to manage socio-psychological, moral, generally-cultural processes in their team and own their management communication and their own behavior, then hardly any of them will be managers of the future.

Consequently, the manager must constantly learn and improve his professional skills. So, what is included in the system of professional requirements and skills of a modern leader (manager) by a multinational team? In modern scientific (special) literature, this management activity problematic is widely exposed to light. However, it should be noted that the psychology and pedagogy of the management of multinational teams have not been sufficiently studied $[8 ; 10 ; 14]$.

Analysis of research on professional skills in various fields of activity shows that in identifying its structure, in most cases, the authors use the personality-activity approach and define a complex of professionally important qualities of a particular specialty personality as a component. As for the psychological and pedagogical aspect of governance, its place and role in the system of interethnic-collectivist relations, in the literature we can find only a simple enumeration of individual psychological and pedagogical features and aspects of the managerial profession. Considering the weak degree of this problem aspect development we try to create some collecting image or the system of interrelated components, which characterize psycho-pedagogical professional summand of managerial activity. As it seems to us, the main professional feature of modern management is that the leader, first of all, is a social lecturer and ethnopsychologist (due to the ethnonational specificity of the management object). For instance, the constractive- managerial activity of a manager, his international, communicative-didactic abilities, adroitness, abilities of scientifically-cognitive analysis to read the mood of multinational team and every person individually, skill to communication and contact establishment. To be tactful, empathetic, tolerant, consistent, persistent, far-sighted, respectful, able to take into account individual, age, 
national and other characteristics, master the art of compilation. To encourage people of different nationalities to achieve the desired goals, to obtain mutual results. To be disciplined, observant, consistent, laconic, rationally responsible, to possess innovative personal charisma, to be especially circumspect, fair, diplomatic, etc. At the same time, a modern, professionally competent manager must possess a sufficiently high level of not only psychological, but also pedagogical, general cultural education, to possess the necessary level of psychological and pedagogical skills and knowledge. The latter should be approved and implemented by him in the system of his professional and business experience as qualitative components and indicators of the professional activity of the manager [16; 9].

Thus, the structure of professional mastery of management activity, firstly, includes a system of professional (special) knowledge in the field of management theory, as well as a system of knowledge, skills, attitudes, personality, ethno-national and professionally important qualities and ethnopsychological properties, which determine the universality, uniqueness and individuality of the manager's personality, which should provide an individually creative, original, purposeful and optimal performance of their professional activities. The structure of professional mastery also includes general, general scientific, general cultural, spiritual, ethnopsychological, ethnopedagogical, artistic and creative endowment (high creative, formative, cognitive, value orientational, communicative potential). The high level of ethnological knowledge, skills and habits should also be noted; attitude to professional goals and values as to the motivational, personal, self-subjective, aimed to creativity, creative self-realization. He must be enterprising, initiative, capable to realize his creative goals, creative level of development of special abilities, providing creative freedom in management activities. He is distinguished by a high level of development, cognitive and emotional-volitional activity, emotional enthusiasm, will and enormous capacity for work, a high general culture, erudition, self-awareness as the subject of professional creativity, creative self-realization, etc. [1; 15]

The correlation of professionalism and creative, psycho-pedagogical, nationalspecific components of managerial activity form, as we see it, the model of components of professionalism. It is the creative personality that has a broad creative orientation, creative abilities, creative thinking, an individual-creative character of applying various knowledge, skills and skills in his professional activities.

Thus, the addition of a holistic, activity-oriented, personal approach to the analysis of the structure of professional mastery by an individual and creative manager, which determines the highest level of managerial activity - professional skill as a synthesis of professionalism "generally speaking", creativity and spirituality, allows us to identify a new qualitative level of components in its structure. In this sense, the management of a multiethnic team is a particularly specific intellectual, creative, sociopsychological process (the leader as an architect, director, conductor, social teacher, etc.). Therefore, all listed above professionally and organically demanded ethno-psychological-pedagogical, subject (artmaking) newgrowthes are system-forming components in the overall structure of professional (managerial) skill. Professional orientation, professional thinking, professional selfidentification should naturally correspond to this creative level.

It should be noted that managerial activities, taking into account the multi-nationality of the team, is a kind of "possession of several kinds of professional activity", it is a system of diverse and multifarious activities. There is the recognition of the social usefulness and significance of one's work in a specific social sphere, the creation of conditions for the spiritual development of various ethnic personalities, the success and evaluation of people, and the highest sense of satisfaction from constant staying with people, the promotion of the latter in the creative process, awareness of demand, etc. Considering the signs and components of the motivation of management activities, we believe that management ac- 
tivities should be professionally appropriate, individually creative and optimally motivational in nature, taking into account the professional and ethnonational specificity of the management object.

\section{Лumepamypa}

1. Аверин Ю.П. Люди управляют людьми: модель социологического анализа. М., 2016.

2. Аверченко Л.К. Психология управления. Новосибирск, 2015.

3. Агеева Н.A. Теоретическое обоснование биоэтики в контексте гуманизма // Экономические и гуманитарные исследования регионов. 2014. № 4.

4. Ананьев В.Г. Психология педагогической оценки. М., 2014.

5. Ворожко Ю.Н., Несмеянов Е.Е., Руденко А.М. Философия самореализации личности в современной культуре. Новочеркасск, 2015.

6. Джиоева Д.А., Камалова О.Н. Значение сенсорных технологий в жизнедеятельности человека // Экономические и гуманитарные исследования регионов. 2011. № 1.

7. Добрович А.Б. Воспитателю о психологии и психогигиене общения. М., 2013.

8. Журавлев В.И. Основы педагогической конфликтологии. М., 2015.

9. Камалова О.Н., Жолобова И.К. Основные тенденции и инновации в системе отечественного образования // Гуманитарные и социальные науки. 2016. № 1.

10. Кузьмина Н.B., Реан А.A. Профессионализм педагогической деятельности. СПб., 1993.

11. Лекторский В.А. О толерантности // Философские науки. 2016.

12. Майерс Дэвид. Социальная психология. СПб., 2014.

13. Межнациональные отношения в России и СНГ: Семинар Московского центра Карнеги. Вып. 1. М., 2014.

14.Drobotya N., Chaplygina E., Kamalova O., Sklyarova E. Drobotya N., Chaplygina E., Kamalova O., Sklyarova E. Contribution of researchers of Rostov state medical universityto health development of Black Sea region // Научный альманах стран Причерноморья. 2017. № 1 (9).

15. Mustafaeva M., Mustafaev F., Mustafaev M. Comparative analysis of modern dagestan student youth value orientations // Научный альманах стран Причерноморья. 2016. № 4 (8).

16. Mustafaeva G., Mustafaev M. Role of ethno-confessional factor in international communication inregions of traditional islam spread // Научный альманах стран Причерноморья. 2017. № 1 (10).

\section{References}

1. Averin Yu.P. People control people: a model of sociological analysis. M., 2016.

2. Averchenko L.K. Psychology of management. Novosibirsk, 2015.

3. Ageeva N.A. Theoretical substantiation of bioethics in the context of humanism // Economic and humanitarian studies of regions. 2014. No 4.

4. Ananyev V.G. Pedagogical evaluation Psychology. M., 2014.

5. Vorozhko Yu.N., Nesmeyanov E.E., Rudenko A.M. Philosophy of self-realization of personality in modern culture. Novocherkassk, 2015.

6. Dzhioeva D.A., Kamalova O.N. The importance of sensory technologies in human life // Economic and humanitarian studies of regions. 2011. No 1.

7. Dobrovich A.B. To the educator about psychology and psychohygiene of communication. M., 2013. 
8. Zhuravlev V.I. Fundamentals of pedagogical conflictology. M., 2015.

9. Kamalova O.N., Zholobova I.K. Main trends and innovations in the system of national education // Humanities and social sciences. 2016. No. 1.

10. Kuzmina N.V., Rean A.A. Professionalism of pedagogical activity. StP., 1993.

11. Lectorskii V.A. About Tolerance // Philosophical Sciences. 2016.

12. Myers David. Social Psychology. StP., 2014.

13. Interethnic relations in Russia and the CIS: Seminar of the Carnegie Moscow Center. No. 1. M, 2014.

14.Drobotya N., Chaplygina E., Kamalova O., Sklyarova E. Drobotya N., Chaplygina E., Kamalova O., Sklyarova E. Contribution of researchers of Rostov state medical university to health development of Black Sea region // Science almanac of Black sea region countries. 2017. No 1 (9).

15. Mustafaeva M., Mustafaev F., Mustafaev M. Comparative analysis of modern dagestan student youth value orientations // Science almanac of Black sea region countries. 2016. No 4 (8).

16. Mustafaeva G., Mustafaev M. Role of ethno-confessional factor in international communication inregions of traditional islam spread // Science almanac of Black sea region countries. 2017. No 1 (10). 